\title{
Implementasi Manajemen Mutu Terpadu (Total Quality Management) di Sekolah
}

\author{
Desi Ratna Yuli, Rusdinal, Hade Afriansyah \\ Universitas Negeri Padang \\ Indonesia \\ Email : desriratnayuliap@gmail.com
}

Abstrak- Quality is very important in education. We all admit, right now there are indeed problems in the education system. Middle school or college graduates are not ready to meet community needs. This problem affects the community. Anticipating changes that are so fast and the challenges that are getting bigger and more complex, there is no other way for the government to function as an organizer of development in the field of education and educational institutions to seek every means to increase the competitiveness of graduates and other academic products among others, achieved through improving the quality of education. So there are several principles that need to be considered in integrated management, namely: (1) Organizations that focus on achieving customer satisfaction, (2) Leadership, (3) Engagement of all organizational participants (People Organization) ), (4) Approaches that emphasize Process
Approach, (5) Application of management using a System Approach,

(7) Continuous improvement steps (Continual Improvement or Kaizen), (8) nine fact based decisions (Factual Apprecision Making)

Keywords: management, quality, integrated, education, implementation

\section{PENDAHULUAN}

Manajemen Mutu TerpaduMMT(Total Quality Management-TQM) merupakan suatu sistem nilai yang mendasar dan komperhensip dalam mengelola organisai dengan tujuan meningkatkan kinerja secara berkelanjutan dalam jangka panjang dengan memberikan perhatian secara khusus pada tercapainya kepuasan pelanggan dengan tetap memperhatikan secara memadai terhadap terpenuhinya kebutuhan seluruh stakeholders organisasi yang bersangkutan. Masalah kualitas dalam 
MMT menuntut adanya keterlibatan dan tanggung jawab semua pihak dalam organisasi.

- - Tuntutan akan lulusan lembaga pendidikan yang bermutu semakin mendesak karena semakin ketatnya persaingan dalam lapangan kerja. Salah satu implikasi globalisasi dalam pendidikan yaitu adanya deregulasi yang membuka peluang lembaga pendidikan ( termasuk perguruan tinggi asing) membuka sekolahnya di Indonesia. Oleh karena itu persaingan di pasar kerja akan semakin berat.

Mengantisipasi
perubahan yang begitu cepat serta
tantangan yang semakin besar dan
kompleks, tiada jalan lain bagi pemerintah
dalam fungsinya sebagai penyelenggara
pembangunan di bidang pendidikan dan
lembaga-lembaga pendidikan untuk
mengupayakan segala cara untuk
meningkatkan daya saing lulusan serta
produk-produk akademik lainnya, yang
antara lain dicapai melalui peningkatan
mutu pendidikan.

\section{METODE}

Artikel ini disusun dengan menggunakan metode kajian literatur, yang mana dalam penyusunannya artikel ini mengambil bahan- bahan dan merujuk pada berbagai sumber baik dari jurnal, buku dan juga sumber-sumber lainnya yang mendukung dalam bahasan dalam artikel ini. Artikel ini disusun dengan sistematis dan terarah yang mana yang artikel ini dimulai dari bagaimana pentingnya pokok bahasan, dilanjutkan dengan membahas teori-teori yang berhubungan dengan bahasan artikel. Yang kemudian dari teori-teori yang di kumpulkan dari berbagai sumber tersebut di analisis dan dipelajari sehingga menghasilkan pengetahuan baru yang membahas pokok bahasan artikel tersebut.

\section{KAJIAN TEORI DAN}

\section{PEMBAHASAN}

\section{A. Konsep dasar Manajemen Mutu terpadu}

Definisi mengenai MMTP mencakup dua komponen yakni apa dan bagaimana menjalankan MMTP. Dalam MMTP, pelanggan adalah yang berkuasa atau sebagai raja yang harus dilayani dengan sebaik-baiknya.

MMTP menurut beberapa tokoh. Menurut West Burham, MMTP adalah semua fungsi dari organisasi sekolah ke dalam falsafah holistis yang dibangun berdasarkan konsep mutu, kerta tim, produktivitas, dan prestasi, serta kepuasan pelanggan. MMTP menurut Sallis, ialah 
menciptakan budaya mutu dimana tujuan setiap anggota ingin menyenangkan pelanggannya, dan di mana struktur organisasinya mengizinkan untuk mereka berbuat seperti itu. MMTP ialah suatu sistem manajemen yang menyangkut mutu sebagai strategi usaha dan berorientasi pada kepuasan pelanggan dengan melibatkan seluruh anggota organisasi.MMTP adalah totalitas yang memerintahkan setiap orang dalam organisasi dilibatkan dalam upaya melakukan peningkatan atau perbaikan. MMTP diartikan sebagai setiap orang dalam lembaga apa pun yang status, posisi, dan perannya adalah manajer dari tanggung jawab yang dimilikinya.

MMTP menyangkut filosofi dan metodologi. Filosofinya ialah pola pikir untuk mengadakan perbaikan terusmenerus, dan metodologinya ialah menjelaskan alat-alat dan teknik-teknik seperti curah pendapat dan analisis medan kekuatan yang digunakan sebagai sarana untuk melakukan perbaikan terus-menerus. Berdasarkan uraian di atas, dapat disimpulkan bahwa MMTP ialah budaya peningkatan mutu pendidikan secara terusmenerus, fokus pada pelanggan sekolah, keluarga, masyarakat, dan pemerintah.

Untuk menghasilkan mutu, menurut Slamet (dalam Bresman, 2009: 79) terdapat empat usaha mendasar yang harus dilakukan dalam suatu lembaga pendidikan, yaitu:

1. Menciptakan situasi "menangmenang" (win-win solution) dan bukan situasi "kalah-menang" diantara pihak yang berkepentingan dengan lembaga pendidikan (stakeholders). Dalam hal ini terutama antara pimpinan lembaga dengan staf lembaga harus terjadi kondisi yang saling menguntungkan satu sama lain dalam meraih mutu produk/jasa yang dihasilkan oleh lembaga pendidikan tersebut.

2. Perlu ditumbuhkembangkan motivasi instrinsik pada setiap orang yang terlibat dalam proses meraih mutu. Setiap orang dalam lembaga pendidikan harus tumbuh motivasi bahwa hasil kegiatannya mencapai mutu tertentu yang meningkat terus menerus, terutama sesuai dengan kebutuhan dan harapan pengguna/langganan.

3. Setiap pimpinan harus berorientasi pada proses dan hasil jangka panjang. Penerapan manajemen terpadu dalam pendidikan bukanlah suatu proses perubahan jangka pendek. Penerapan manajemen mutu terpadu dalam pendidikan bukanlah suatu proses perubahan jangka pendek, tetapi 
usaha jangka panjang yang konsisten dan terus menerus.

4. Dalam menggerakkan segala kemampuan lembaga pendidikan untuk mencapai mutu yang ditetapkan, haruslah dikembangkan adanya kerjasama antar unsur-unsur pelaku proses mencapai hasil mutu. Janganlah diantara mereka terjadi persaingan yang mengganggu proses mencapai hasil mutu tersebut. Mereka adalah satu kesatuan yang harus bekerjasama dan tidak dapat dipisahkan satu sama lain untuk menghasilkan mutu sesuai yang diharapkan.

Dalam kerangka manajemen pengembangan mutu terpadu, usaha pendidikan tidak lain adalah merupakan usaha "jasa" yang memebrikan pelayanan kepada pelanggannya yang utamanya yaitu kepada mereka yang belajar dalam lembaga pendidikan tersebut. Para pelanggan layanan pendidikan dapat terdiri dari berbagai unsur paling tidak empat kelompok.

B. Prinsip - prinsip manajemen mutu terpadu dalam pendidikan

Menurut Dean sebagaimana dikutip oleh Ali Djamhuri (2001:8) prinsip umum Manajemen Mutu Terpadu meliputi:
1. Organisai yang memfokuskan pada ketercapaian kepuasan pelanggan (Customer Focus Organization). Organisasi dalam hal ini manajemen harus dapat mengoptimalkan seluruh potensi dan sumber daya organisasi dan sistem yang ada untuk menciptakan aktivitas terhadap tercapainya kepuasan pelanggan. Tercapainya kepuasan pelanggan meliputi seluruh stakeholders, baik yang berada didalam organisasi maupun di luar organisasi.

\section{Kepemimpinan (Leadership)}

Kepemimpinan merupakan proses untuk mempengaruhi pihak lain untuk mencapai tujuan organisasi. Oleh karenanya pemimpin harus memiliki visi dan misi yang jelas, sehingga keduanya dapat dituangkan dalam kebijakan yang akan diambil.

3. Keterlibatan seluruh partisipan organisasi (People Organization) Seluruh komponen di dalam suatu organisasi harus dilibatkan. Artinya seluruh sitivitas organisasi harus selalu berusaha untuk melakukan perbaikan secara terus menerus. Perbaikan bukan hanya dari pihak kepala sekolah, guru, tenaga administrasi, tetapi semua sivitas sekolah harus memiliki komitmen untuk melakukan perbaikan. Dengan 
kata lain semua sivitas sekolah harus dilibatkan dalam upaya memberikan pelayanan yang sebaik-baiknya kepada para pelanggan.

4. Pendekatan yang menekankan pada perbaikan proses (Process Approach) Kurangnya dukungan sistem informasi dan alat ukur keberhasilan MMT berasumsi bahwa output akhir suatu organisasi tidak semata-mata dilihat secara parsial, tetapi suatu proses yang panjang. Proses tersebut dilakukan secara sadar oleh setiap individu. Kegiatan tersebut juga dilakukan saling terkait satu dengan lainnya sehingga menghasilkan outputorganisasi. Jelassnya tamatan atau lulusan bukan semata-mata produk tenaga akademik, atau karyawan sajak, tetapi menyangkut proses yang melibatkan tenaga akademik, karyawan, kepala sekolah, murid, orang tua, pemerintah, dunia usaha, dan masyarakat luas, yang tentu saja proporsinya berbeda satu sama lainnya.

5. Penerapan manajemen dengan menggunakan pendekatan sistem (System Approach) Dalam konteks organisasi, upaya menyempurnakan proses tertentu harus dikaitkan dengan proses lainnya. Oleh karena pihak-pihak yang terkait dengan proses tersebut merupakan tangkaian yang tidak dapat dipisahkan. Tuntutan peningkatan kualitas pembelajaran tidak dapat dilakukan oleh tenaga pengajar semata, tetapi harus pula melibatkan aspek ketatausahaan, kepemimpinan, fassilitas, dan penciptssn organisasi yang optimal atau mendukung.

6. Langkah perbaikan yang dilakukan secara terus menerus (Continual Improvement atau Kaizen) Inti perbaikan yang dilakukan secara terus menerus oleh pimpinan adalah adanya human resources empowerment baik bagi tenaga edukatif maupun administratif. Realitas menunjukkan belum seluruhnya pemimpin organisasi menyadari arti pentingnya pemberdayaan tenaga akademik dan administratif. Para pimpinan sering lebih mementingkan pengembangan fasilitas atau pegembangan fasilitas. Hal ini ditunjukkan oleh adanya anggaran pendidikan dan pelatihan untuk kedua tenaga tersebut tidak setidak-tidaknya kurang berimbang dibandingkan dengan anggaran pembangunan fisik.

7. Penerapan pengembilan keputusan didasarkan fakta (Factual Apprecision Making) Manajemen 
Mutu Terpadu-MMT berdasarkan pada kepuasan pelanggan. Oleh karenanya maka orientasi MMT harus mendasarkan pada fakta yang diinginkan oleh pelanggan. Pada sisi lain kepuasan berkaitan dengan kualitas. Implikasinya kualitas kepuasan tersebut harus dapat diukur dan dapat dilakukan monitoring setiap saat. Dengan demikian, pemimpin organisasi harus dapat menciptakan dan mengembangkan alat ukur sebagai keberhasilan suatu lembaga

\section{Pembahasan}

Pada dasarnya TQM dalam dunia pendidikan menurut frankin P. schargel (1994:2) dalam buku Syafarudin (2002: 35 ) dikatakan bahwa Total qulity management education is process wich involves focusing on meeting and exceeding custumer expectations, continous impruvment, sharing responsibilities with employess, and reducasing scraf and rework. Artinya bahwa mutu terpadu pendidikan dipahami sebagai suatu proses yang meilibatkan pemusatan pada pencapaian kepuasan harapan pelanggan pendidikan, perbaikan terus menerus, pembagian tanggung jawab, dengan para pegawai, dan pengurangan pekerjaan tersisa dan pengerjaan kembali.Hampir senada dengan pendapat Frankin dalam artikel Dheeraj mehrotra menekankan pada penerapan manajemen mutu yang disesuaikan dengan sifat-sifat dasar pendidikan. Sisi pelanggan yaitu siswa, orang tua dan masyarakat menjadi fokus utama.Dengan mengkombinasikan prinsip-prinsip tentang mutu oleh para ahli dengan pengalaman praktek telah dicapai pengembangan suatu model sederhana akan tetapi sangat efektif untuk mengimplementasikan manajemen mutu terpadu di sekolah TQM menawarkan filosofi, metode, dan strategi baru perbaikan mutu pendidikan. Untuk memperbaiki mutu pendidikan diperlukan keterlibatan semua pihak. TQM bertujuan memberikan kepuasan terhadap kebutuhan pelanggan seeisiensi mungkin, Bahkan TQM dalam pendidikan dapat menguntungkan semua pihak dengan syarat manajer yang memperbaiki kinerja pegawai dan organisasi secara terus menerus sejalan perkembangan internal dan eksternal oraganisasi.

Adapun jargon utama yang mendasari falsafah manajemen mutu terpadu terfokus pada pernyataan " Do the right things, first time,every time" ( kerjakan sesuatu yang benar sejak pertamakali, setiap waktu ). Dalam hal ini, mutu terpadu pendidikan dipahami sebagai suatu proses yang melibatkan pemusatan pada pencapaian 
kepuasan harapan pelanggan pendidika, perbaikanterus menerus, pemabagian tanggung jawab dengan para pegawai danpengurangan pekerjaan tersisa dan pengerjaan kembali( ulang). Manajemen mutu pendidikan bukan hal baru dalam perkembangan ilmu manajemen modern, terutama di Negara- Negara maju yang pendidikannya sudah mencapai kemajuan dengan dimulai dari gerakan mutu.

Keberadaan manajemen mutu terpadu dalam pendidikan bukanlah suatu strategi manajemen yang tiba- tiba muncul, tetapi telah dilatarbelakangi perkembangan scientific management dan perkembangan dunia industry di jepang, amerika, dan Inggris. Semua itu memunculkan alas an rasional bagi penerapannya dalam dunia pendidikan .

Alat dan teknik perbaikan mutu terpadu dalam pendidikan

\section{Gugah Pikiran}

2. Jaringan kerja kemiripan

3. Diagram tulang ikan

4. Analisis keadaan lapangan

5. Pendiagraman

6. Diagram arus

7. Analisis pareto

8. Pengukuran kinerja

9. Pemetaan arah karier

Manajemen mutu terpadu merupakan strategi pengelolaan mutu yang berusaha memenuhi harapan pelanggan yang dilakukan secara bertahap dan terus menerus untuk mencapai peningkatan mutu . Penerapan konsep manajemen mutu terpadu ini berartimengutamakna pelayanaan terhadap pelajar dalam meningkatkan mutu lulusan, atau upaya perbaikan sekolah secara komprehensif.Didalamnya tentu harus ada upaya terpadu dalam meperbaiki kultur sekolah dan hal itu dimulai dari tindakan manajemen.Penerapan manajemen mutu terpadu dalam pendidikan melewati beberapa proses sejak dari persiapan, perencanaan, dan pelaksanaan mutu jasa layanan pendidikan yang diharapkan para pelanggan pendidikan. Menurut Erra (Erra Yusmina, 2014) Sekolah dapat diartikan sebagai sebuah lembaga untukmelakukan proses belajar, mengajar, menurut tingkatan dan jurusannya. Terkait pendidikan kejuruan pada dasarnya memiliki variasi sesuai dengan subjektivitas pada perumusannya. Dalam rangka pengembangan atau peningkatan mutu sebuah sekolah, dapat dicapai melalui perencanaan dan program yang matang dengan mewujudkan visi dan misi serta menerapkan strategi yang tepat. Pemenuhan harapan pelanggan pendidikan menjadi paradigma manajemen mutu yang harus terpenuhi, sehingga mereka yang 
putus sekolah dan pengangguran bisa diperkecil dalam dunia pendidikan kita.

\section{KESIMPULAN}

MMTP ialah suatu sistem manajemen yang menyangkut mutu sebagai strategi usaha dan berorientasi pada kepuasan pelanggan dengan melibatkan seluruh anggota organisasi.MMTP adalah totalitas yang memerintahkan setiap orang dalam organisasi dilibatkan dalam upaya melakukan peningkatan atau perbaikan. MMTP diartikan sebagai setiap orang dalam lembaga apa pun yang status, posisi, dan perannya adalah manajer dari tanggung jawab yang dimilikinya. Manajemen mutu terpadu merupakan strategi pengelolaan mutu yang berusaha memenuhi harapan pelanggan yang dilakukan secara bertahap dan terus menerus untuk mencapai peningkatan mutu . Penerapan konsep manajemen mutu terpadu ini berartimengutamakna pelayanaan terhadap pelajar dalam meningkatkan mutu lulusan, atau upaya perbaikan sekolah secara komprehensif.Didalamnya tentu harus ada upaya terpadu dalam meperbaiki kultur sekolah dan hal itu dimulai dari tindakan manajemen.Penerapan manajemen mutu terpadu dalam pendidikan melewati beberapa proses sejak dari persiapan, perencanaan, dan pelaksanaan mutu jasa layanan pendidikan yang diharapkan para pelanggan pendidikan. Pemenuhan harapan pelanggan pendidikan menjadi paradigma manajemen mutu yang harus terpenuhi, sehingga mereka yang putus sekolah dan pengangguran bisa diperkecil dalam dunia pendidikan kita.

\section{DAFTAR PUSTAKA}

Agus Suwignyo, 2008. Pendidikan Tinggi \& Goncangan Perubahan. Yogyakarta: Pustaka Pelajar

Ahmad Tafsir, 2011. Ilmu Pendidikan Dalam Perspektif Islam. Bandung: PT. Remaja Rosdakarya

Sutrisno \& Muhyidin Albarobis, 2012. Pendidikan Islam Berbasis Problem Sosial. Jogjakarta: Ar-Ruzz Media Husaini Usman, 2014. Manajemen Teori Praktik dan Riset Pendidikan. Jakarta: PT Bumi Aksara

Oemar Hamalik, 2010. Manajemen Pengembangan Kurikulum. Bandung: PT Remaja Rosdakarya.

Erra Yusmina. (2014). IMPLEMENTASI MANAJEMEN MUTU TERPADU

DALAM PENINGKATAN KINERJA SEKOLAH PADA SMK NEGERI 1 BANDA ACEH.

Pedadogi, 4(2), 11. Retrieved from http://www.jurnal.unsyiah.ac.id/JAP/ article/view/2520/2367 